\title{
Justicia liberal: teleología y cosmovisión
}

\section{Liberal Justice: Teleology and Worldview ${ }^{1}$}

\author{
Fernando Aranda Fraga ${ }^{1}$ \\ Universidad Adventista del Plata, Argentina ${ }^{1}$ \\ Orcid ID: https://orcid.org/0000-0002-9324-7605 ${ }^{1}$
}

\begin{abstract}
Resumen
La doctrina filosófica y económica de la "mano invisible" fue formulada por el filósofo escocés Adam Smith (1723-1790), quien es hoy considerado uno de los mayores exponentes de la economía clásica, como así también el padre de la economía política. Su obra capital es La riqueza de las naciones. La tesis principal de su obra es que la clave del bienestar social radica en el crecimiento económico y este se potencia mediante una adecuada división del trabajo y la competencia entre seres humanos libres, iguales y relativamente egoístas. Aquí se analiza cómo ello surgió durante la Modernidad, e incluso profundizando en la escolástica tardía, rastreando en Ockham sus remotos orígenes, la doctrina liberal de los derechos y de la seguridad; en definidas cuentas, la idea de justicia y la cosmovisión que la sostiene. En el interregno de ambas épocas no es posible eludir el hecho contundente de la transformación del derecho natural en derecho positivo y su impacto en la política, la sociología y la economía. Esta escuela se completa y aplica mayormente a la economía y la teoría social contemporáneas con el desenlace teórico sobre la teoría liberal de la justicia que desarrolló John Rawls, especialmente entre los años 1971-1995. A estas conexiones y su crítica nos dedicaremos en lo que sigue.
\end{abstract}

Palabras clave: Liberalismo, justicia, cosmovisión, Modernidad, ley

\begin{abstract}
The philosophical and economic doctrine of the "Invisible Hand" was formulated by the Scottish philosopher Adam Smith (1723-1790), who is considered one of the greatest exponents of classical economics, as well as the father of political economy. His capital work is The Wealth of Nations. The main thesis of his work is that the key to social welfare lies in economic growth and this is enhanced by an adequate division of labor and competition between free, equal and relatively selfish human beings. Here we analyze how it emerged during Modernity, and even deepening in the last scholastic tracing in Ockham its remote origins, the liberal doctrine of rights and security, in definite accounts, the idea of justice and the worldview that sustains it. In the interregnum of both ages, it is not possible to avoid the convincing fact of the transformation of natural law into positive law and its impact on politics, sociology and economics. This school completes and applies mainly to contemporary economics and social theory with the theoretical outcome on the liberal theory of justice developed by John Rawls, especially between the years 1971-1995. We will dedicate ourselves to these connections and their criticism in what follows.
\end{abstract}




\section{Introduction}

The philosophical and economic doctrine of the "invisible hand" was formulated by Scottish philosopher Adam Smith (1723-1790), who is considered one of the greatest exponents of classical economics, as well as the father of political economy. His most influential work is The Wealth of Nations. The main thesis of his work is that the key to social welfare lies in economic growth and this is enhanced by an adequate division of labor and competition between free, equal and relatively selfish human beings. The division of labor is deepened in the extent to which there is an expansion of markets and therefore of specialization.

Adam Smith considers free competition as the basis of economic development, claiming that the contradictions generated by market laws are corrected by what he calls the "invisible hand" of the system. This invisible hand is shaped by the sum of individual interests and passions, which, seeking all and always their own profit, contribute to the achievement of the common good capable of giving cohesion and secure foundation to society. We are situated at the very base of Hobbes' modern liberalism, and later assimilated by Locke, Hume and Rousseau, who conformed the universal social doctrine adopted by modern and contemporary democracies. Thus, in our time, it was mainly Rawls and Habermas who went deeper into social and legal theory in order to justify liberalism, while at the same time shielding it from the nineteenth-century Marxist criticism, its heir communism, and other critical fundamentalisms of the market economy and scarcely controlled individual liberties (Libertarianism, Entitlement Theory, eg Von Hayek and Nozick).

Here we analyze how the liberal doctrine of rights and security emerged during Modernity, definitely, the idea of justice and the worldview that sustains it. In this regards, as its immediate precedent, we also review such influences in the late scholastic school, tracing its remote origins in Ockham. In the interregnum of both eras it is not possible to avoid the forceful fact of natural law transformation into positive law and its impact on politics, sociology and economics. This school is completed and applied mainly into contemporary economics and social theory with the theoretical outcome on the liberal theory of justice developed by John Rawls, especially between the years 1971 and 1995. We will dedicate ourselves to these connections and their criticism in what follows. 


\section{Fundamentals of the liberal worldview of society}

The liberal conception of justice has remained, through the philosophical history of its own internal development, closely linked to artificial root a social theory, in which the State and society have their reason for being and ultimate source in satisfying needs that are strictly individual. In this conventional framework, the State is no longer an end nor the proper sphere in which individuals develop as naturally social beings (Aristotle, Thomas Aquinas), but a means, whose goal is to provide security to their components, so that they, as social atoms, meet their needs for survival and well-being.

From this perspective, the State is able to sustains itself to the extent that it is able to generate the legal conditions that allow the institutions to develop their individual goals, in the most efficient way possible. These juridical conditions are constructed from specific circumstances in which the life of the individuals is developed, in agreement with the teleology that assumes liberalism as a system. It is not only imposed as a political ideology, but as a worldview (Weltaunchauung), which guides the life of human beings as a whole. These are self-assumed atoms (monads, in the manner of Leibniz), whose needs, strictly individual -and even social ones- have to be satisfied in the most efficient way possible, putting their own interests before the social ones. At the same time, establishing a legal framework that prevents the juxtaposition of these interests among themselves, making sure that there is no coalition between individuals that disturb social peace (pax societas). If this occurs, safety itself, and consequently the individual wellbeing achieved, is seriously jeopardized.

We must remember here that the roots of this ideological conception of society and of life have not generally been well known. It happens that we are not usually familiar with the currents of political thought that have had part and voice in the formation of the structure of liberal thought. Behind his well-known spokespersons, a bundle of legal, political, ethical, and even metaphysical concepts - despite John Rawls, and including his legal ethics as a system ${ }^{2}$ - whose trail is lost in the labyrinths of time, even middle centuries of the Roman Empire, and intermingled with certain nuances proper to Christianity.

It is possible to point out three great thinkers, who were building in their respective eras the bases and significance of liberalism as forgers of social, political, legal and economic theory, focusing specifically on their theories of society and Justice. Both theories, it is worth clarifying, intimately linked, since one is incapable of existing without 
the other. They require each other, forming a unity from which the liberal ideology is founded as a political system. ${ }^{3}$

Briefly, we will analyze part of the political philosophy of these three authors, whose ends are separated in time by more than six centuries. Their choice may seem a bit capricious, a priori, although it should not be seen as far as its justification must be based, as we try, on the thematic and epochal representativeness of them. We refer to Ockham (1280-1349), Hobbes (1588-1679) and Rawls (1921-2002).

\section{Ockham: Decline of the universals and popular sovereignty}

With Ockham, the idea of a social pact takes on a great deal of force, even if it means, with Brian Tierney, who used the language of the canonists, medieval jurists of the thirteenth century who preceded him. ${ }^{4}$ Ockham will be one of the major responsible for intellectualizing a movement that had already begun to materialize in the popular masses, giving it a formal closure and a strictly scholastic language. This will be done in the perspective of three key concepts, the cornerstones of secularism, as well as grounds for the new modern political ideas: 1) his idea of separation of powers, temporal and spiritual, doctrine that he develops thoroughly in his political work $;^{5}$ 2) his notion of subjective rights, in conjunction with his conception of the emergence of property, starting from the entrance of sin in the world with Adam and Eve in Eden; and (3) its emphasis on the sovereignty of the people, the basis of the entire contractualist and fundamental reason for existence of humanism, which in itself conveys the essence of this doctrine, to its culmination in modern and contemporary individualism (Tierney, 1996, 2). To these three ideas must be added, according to the hermeneutics adopted by the whole of its philosophy, a more encompassing and basic aspect of the concepts mentioned above; we refer to his epistemological, metaphysical and theological writings. ${ }^{6}$ In this field Ockham has stood out as the main representative of nominalism, epistemic theory that later Hobbes assumes to the letter and uses as a semiotic and linguistic foundation of his whole system (Hobbes, 1969, 13).

\section{Hobbes: From the determinist mechanism to social materialism}

On a scientist and humanist background, according to the English spirit and its time, Hobbes's political thought stands out, his main interest was to give an explanation and justification on the constitution of society and government. For this Hobbes assumes the mechanistic conception of the world, in force during Modernity, and the classically modern secularist motivation. These were the basic elements which Hobbes, with greater 
force than Ockham, gave philosophical origin to the social contract or pact, by which the existence of civil and political society must be formalized. ${ }^{7}$ The nominalist character of Hobbesian theory of knowledge, and the influence of Ockham, are reflected in his statements of Ch. IV of the Leviathan, about the non-existence of universals, going even further than his English predecessor. According to Hobbes, "the terms used by language are not constituents of things, but mere conventional signs created for communication purposes" (Aranda Fraga, 2003, 44).

Just as in the physical world, according to Hobbes, a strict doctrine of the materialist, deterministic and mechanistic, also occurs in the realm of the human and the social. To this must be added his anti-finalist conception and the political revolutions of the time, marked, in England, by the civil and political disorder, anarchic state in which the society of his time existed. This fact undoubtedly prompted him in his quest for a longed-for social state of peace, order and security. If to all this we add the strong influence of the spirit of his time, as to the prevailing order in mathematical-geometric reasoning, which will lead Hobbes $(1966,50-51)$ to the use of this methodology in the construction of his moral and political work, we have something clearer is the nutritious soil of a tradition that dominated the political and social scene during Modernity: the contractualist tradition.

\section{The social pact, legal-political inheritance of the modern worldview}

Hobbes inaugurates a school of political philosophy for Modernity and therefore constitutes one of the main milestones in the history of universal political theory. His thought will be resumed a little later, although nuanced, by Locke, first, assimilating his theory of the social contract to a more naturalistic and democratic position, and later by Rousseau, a political position through which he tried to mediate between the positive freedom of the ancient Greeks and the negative, limited, current in the modern age. The original Rousseauist reading of politics presents us with an Aristotle read in a modern key. But it was Hobbes who made history as the great innovator of the time, precisely because of his break with the era that preceded him and for having taken a second major step in the history of contractualism.

\section{Formal concept of justice}

As for his theory of justice, according to Hobbes, it is an empty law, like Kant's categorical imperative. His maxim appears in chapter XV of the Leviathan, when he formulates his third natural law: "that men fulfill the covenants made" (Hobbes, 1966, 
130). Justice does not exist in men's natural state, it only appears on the scene once the political society is contractually formed. Therefore, there is no property in the natural state, but there is only property when there is justice, since "justice is the constant will of giving to every man his own" (130-131). This definition allows him to affirm that it is not possible to speak of property in a condition in which neither justice nor injustice can be spoken, since these names only fit in the State. This is why only in the State can there be property.

On the other hand, Hobbes seeks to reinforce equality that was not stable in the natural condition, through the law, sanction and coercive power of the sovereign, who before his subjects represents a greater inequality, but precisely this is what allows those subjects to remain the same each.

Hobbes becomes the political theorist who inaugurates the formal conception of justice. Righteous are the acts that conform to the law and unjust those who do not conform to it. Before the covenant there is, according to Hobbes, no justice or injustice; after the pact, justice lies in its conservation. Such formal and legal consideration of justice does not consider the nature and purpose of duty, but only its fulfillment. Justice is constituted in the foundation of obedience to positive law and in this same it finds its sanction. The ultimate aim of justice is the reason why the covenant is made, that is, to ensure self-preservation, and thereby property. But its nature is conventional.

\section{John Rawls and the inheritance of contractualism}

In Rawls there is no historical pact, but there is the contractual fact, an absolutely constructed hypothetical device. Through this artifice, mediated by a veil of ignorance, men are placed deprived of certain knowledge about what the future will be like for them, so that they are in full impartial condition to choose basic principles that will determine the conception of justice by which they will be governed. This possibility of creating an artificial condition that has to control all its future and to govern relations in society, available to men, not to have some kind of natural or divine right, but merely because they decide, by themselves, to stipulate the conditions for the existence of a just society. Society that is governed by impartiality and for which is only accountable for what we call "human rights" or "law of nations," in all of which is denoted the influence of the Kantian concept of "autonomy of the will" 8 .

For Rawls there is an explicit -though hypothetical- contract that produces absolutely artificial, albeit supposedly impartial, criteria of justice by which institutions, 
and hence society as a whole, are to be ruled. There is no natural justice as the basis of the principles chosen by the covenants; in this he is indebted to David Hume. What is agreed is not to form a society, nor the appointment of someone who guarantees its operation. They agree on the principles of justice that are to govern the legislation itself, which is the only thing that ultimately matters in a society -absolutely secularized in the twentieth century- in which the role of the state has been minimized. They agree because this must first result in obtaining personal benefits that are supposed to be fair, and second, in the achievement of a society where cooperation of each other is possible, that is, in which the free market (A. Smith) and to exercise individual freedoms as far as possible. There is no divine command given to the covenants by which they decide to leave the original position in which they are and move to a more just society, as in Ockham, for example. Here the mandate is given by this kind of immanent authority which is the democratic society in which the covenants live and develop their plans of life; in short, liberal democracy and no other.

\section{From homo homine lupus to "well-ordered society"}

However, Rawls must give an answer on how to produce a "well-ordered society," which means that, even if it is not on the brink of civil war, corporate gear is not working optimally. This is ultimately due to the fact that Rawls's societal individuals are similar to the anthropological type described three centuries earlier by Hobbes -the homo homine lupus - because, according to these new contractualists, if society does not progress further, it must be because selfishness, envy, or a passion for style, is preventing it. Consequently, neo-contractualism only becomes anchored in the old Hobbesian anthropology. Hobbes, against Aristotle and St. Thomas Aquinas, endeavored to show that man can't be defined as a "political animal," but, on the contrary, as the "wolf of man." That is to say, it naturally has no tendency to meet in society.

So, know it is clear. What Hobbes wanted was to establish the responsibility and obligation of the existence of society in man himself, resorting to the social contract artifice. Rawls, and the rest of contemporary neo-contractualists, want to go one step further, because at this point there is a police power, installed in the society that formed man himself, agreeing with each other, which prevents its dissolution. But from liberal democracy he pretends otherwise, that he will find it basically in the same kind of procedure that Hobbes and the rest of the modern contractarians had used. Now he wants the liberal state to be a society that progresses, for which it must, in the first place, 
eradicate the envy that exists among the corporate individuals, because of the injustices that they observe and suffer daily in the society in which they live. This envy is originated in selfishness, obviously, and not to stop it, society stagnates.

\section{The Rawlsian principles of justice}

The principles of justice must ensure the basic conditions of liberal democracy. That is to say, they will be based on a terrain already subsumed by a certain liberal conception of justice, artificially created or foreshadowed during the centuries in which the habit of living in a society that has been molded gradually by this political ideology was followed. This will allow everyone to continue with their own plan of life, as long as it does not contradict the established principles of justice and the very foundations of liberal society. Moreover, this "overlapping consensus" allows and does not hinder the implementation of the principles of justice. Society is an artificial product, as much or more than in the case of Hobbes, because the relations between its members are based on principles of justice artificially created (Rawls, 1971, \# 10-11, 52-64, \# 35, 216-221, \# 60, 395-399. Rawls, 1996, \# 8, 208-211). This constitutes a reassurance of the democratic way of life, which is the first of the social duties, within its ideological conception, of course. In short, justice and its definition were transformed into something constructed, and this came to be constituted in the new social paradigm (Rawls, 1999, \# 2, 140-148).

\section{The contemporary political outcome of the liberal worldview}

Each of these thinkers said something very relevant and original at the time and the three stages of the history of liberalism that they determine are, seen in historical perspective, a sort of paradigmatic revival of an ideology, which thus, through it, achieved to make a firm foothold in the history of the West. It is true that it is not possible to speak of "liberalism" either before Ockham, or even because of him, immediately after him, but his interpretation of political power as a reversible reversal of the rights of individuals to their rulers set strong precedents in that history. A theory that will be thoroughly reworked by Hobbes, who was based on a secular worldview of life and a positive legal conception of rights and obligations. Then, Hume, of whom we do not deal with at this time, but who had strong influenced on Rawls, will bring his constructivist conception of morality and an unnatural (therefore artificial, constructed by consensus) interpretation of justice, in a context of total dispossession of metaphysical foundations (Aranda Fraga, 2009, 161172).

All this so that, centuries later, Rawls, without even questioning the origin of 
society, implicitly assuming it as contractual, definitively shapes the concept of man prevailing in liberalism. It does so through an absolute modern theory of justice, inherited from Hobbes and Hume, in its essence, seeking to find the exact point of equilibrium of impartiality. A theory marked by the cardinal value that represents the correct procedure. And also relegating the proclaimed substantivity of the theory to the mentioned "equality of opportunities" and to an "overlapping consensus" on goods and values. In definite accounts, the good of the society, according to Rawls, will be restricted to the establishment, in peace, of a pluralism of ideas and values, consequently, a theory of justice that ends up being constituted in the password key of liberal politics philosophy of our time.

\section{Epilogue: the contemporary legal order}

Society, according to the liberal worldview (Weltaunchauung), is self-supporting where the legal order of the individuals who compose it is secured. Where justice is absent, the social bond is broken, which in itself, according to the anthropological conception that beats in the background of liberalism, is an artificial, that is, unnatural. This framework assumed by liberalism, which we have tried to present very succinctly, is based, in synthesis, on the following precepts or axioms:

- The individual is not naturally a social being. Against St. Thomas Aquinas and Aristotle, there is no so-called "natural politics" of the human being. The very human end -according to liberal ideology- is a basically individual end and not a social goal.

- The individual, as such, seeks the satisfaction of his own interests in the fastest, pragmatic and efficient way possible.

- To the individual, freedom is essential and defines him this way, therefore the individual is a subject of rights. These rights will be inalienable, although limited by the rights of their peers.

- Satisfaction of the indvidual's goals can be assured in a framework of peace and security, never in a situation of war, which is not convenient for the human being.

- So that the individual may be able to exercise his freedom (negative, and no longer positive as it was in Aristotle, on the one hand, and as it was in the Hebrew community of the Old Testament or in primitive Christianity of the first century) and his rights in a situation of peace, must be self-limiting. In a way that their freedom and rights do not collide with the freedom and rights of others, their 
peers. In this way the "invisible hand" can operate in society, efficiently ordering and assuring the interests of individuals and all parties.

- The origin of a liberal conception of justice must no longer be natural but, on the contrary, artificial or conventional, based on tacit or explicit agreements, whose only basic ethical norm requires respect for rules (ironically called "Principles", in some cases) and procedures emanating from the agreements. It will therefore be more important in this worldview, a theory of the Right than a theory of Good (Rawls, 1988, 251-276).

- Therefore, from all this we obtain that all theory of justice, within a liberal conception of society, must respect, to the maximum extent possible, the freedom and rights of individuals; it must regulate its limitations so that the rights of some people do not contradict those of other people; It will also contemplate the voice of minorities. All this, so that a "well-ordered society" can be maintained, in which the teleology of the political system that governs it is guaranteed. The efficiency of a society and of a judicial system will be given, then, by its legal capacity to sustain a social pax, within which the satisfaction of the interests and aspirations of individuals is guaranteed (Kohn, 1996, 42) .

\section{Notes}

${ }^{1}$ This paper is product of a research grant funded by the Faculty of Theology of the Adventist University of Plata, during 2018. The research project was called "Liberal justice: teleology and worldview". A preliminary version of this research was presented by the author during the 8th Annual Symposium of the Society of Adventist Philosophers: "The Invisible Hand? Christ and the Free Markets", that happened in Boston, MA, USA, November 16-17, 2017.

${ }^{2}$ See Rawls, 1985, 223-251.

${ }^{3} \mathrm{~A}$ fourth milestone, the first in chronological terms, would be shaped by the Greek sophists (S. V-IV BC), who were pioneers in thinking about society and the State, as well as the economic relations that occur in them, in contractual terms, through agreements and agreements between equal and free beings.

${ }^{4}$ See Tierney, 1997, specially chapters I \& II of 1rst. Part: "Villey, Ockham and the Origin of Individual Rights", 13-42, and "Origins of Natural Rights Language: Texts and Contexts, 1150-1250", 43-77. 
${ }^{5}$ See Ockham, 1992 \& Ockham, 1974-2002.

${ }^{6}$ See Aranda Fraga, 2005, 11-30.

${ }^{7}$ See Aranda Fraga, 1999, 257-302.

8"It appears to be distinguished from the classic contract theory of the early moderns precisely by not presupposing a set of natural rights as the moral background to a contract that then becomes focused on the political conditions necessary for making those right effective" (Boucher \& Kelly, 1994, 183).

${ }^{9}$ Carlos Kohn sustains the idea that "... contemporary contractualists not only assume the Hobbesian naturalistic model, but, like Adam Smith, rely on their metaphysics" (1996, 42).

\section{References}

Aranda Fraga, F. (1999). El corte epistemológico en la comprensión del origen de la sociedad política a partir de Thomas Hobbes, Estudios Filosóficos, 138(XLVIII), 257-302.

Aranda Fraga, F. (2003). El lenguaje de la ciencia política moderna: Hobbes y el Nominalismo, Logos. Revista de Filosofía, XXXI(91), 23-50.

Aranda Fraga, F. (2005). Ockham: precursor medieval de la ética y la filosofía política modernas, Invenio, 7(14), 11-30.

Aranda Fraga, F. (2009). La justicia política y sin fundamento metafísico de John Rawls, in Oliveira, N. de y Gonzaga de Souza, D. Justiça global e democracia: homenagem a John Rawls (161-172). Porto Alegre: ediPUCRS.

Boucher \& Kelly, eds. (1994). The Social Contract from Hobbes to Rawls. New York: Routledge.

Hobbes, T. (1966). Leviathan. Or the Matter, Forme and Power of A Common Wealth Ecclesiastical and Civil. EW, III, ed. Sir William Molesworth, Second Reprint. London: Scientia Verlag Aalen.

Hobbes, T. (1969). The Elements of Law Natural and Politic, ed. Ferdinand Tönnies and Introduction by M. M. Goldsmith. New York: Barnes \& Nobles.

Kohn, C. (1996). El Leviatán: fin de la historia de la sociedad de mercado, Enfoques $\operatorname{VIII}(1), 40-48$.

Ockham, W. (1974-2002). Opera politica. Vols. I-VI. Manchester: Manchester University Press-Harper \& Row Publishers.

Ockham, W. (1992). A Short Discourse on the Tyrannical Government, ed. A. S. McGrade, trad. John Kicullen. New York: Cambridge University Press.

Rawls, J. (1971). A Theory of Justice, 21th edition. Cambridge, Massachusetts: Harvard University Press.

Rawls, J. (1985). Justice as Fairness: Political not Metaphysical, Philosophy and Public Affairs, 14, 223-251.

Rawls, J. (1988). The Priority of Right and Ideas of the Good, Philosophy and Public Affairs, 17, 251-276.

Rawls, J. (1996). Political Liberalism. New York: Columbia University Press. 
Rawls, J. (1999). The Idea of Public Reason Revisited, in The Law of Peoples with "The Idea of Public Reason Revisited". Cambridge, Massachusetts: Cambridge University Press.

Tierney, B. (1996). The Crisis of Church and State 1050-1300. Toronto: University of Toronto Press.

Tierney, B. (1997). The Idea of Natural Rights. Studies on Natural Rights, Natural Law and Church Law 1150-1625. Atlanta: Scholars Press. 